\title{
Satisfaction Levels of Individuals Who Go to Fitness Centers
}

\author{
Fatih Mehmet Uğurlu \\ High School of Physical Education and Sport, Frrat University, Elazı̆̆g, Turkey
}

Copyright $(2018$ by authors, all rights reserved. Authors agree that this article remains permanently open access under the terms of the Creative Commons Attribution License 4.0 International License

\begin{abstract}
The aim of this study is to determine the satisfaction levels of individuals who go to fitness centers. The model of the survey is a descriptive survey model. The sample of the study consists of 113 participants who were chosen by convenience sampling. The involvement of the participants into the study is based on the volunteerism principle. A survey form was used as the data-gathering tool in the study. The survey form consists of matters intended for personal information and the Sports Facilities Customer Satisfaction Scale. The data analysis in the study was conducted by using SPSS 21 package software. In the data analysis, descriptive statistics such as frequency, percentage, mean, standard deviation, minimum and maximum calculations were used. Additionally, in order to determine the relationship between the personal information and the sports facilities customer satisfaction, Mann Whitney $U$ and Kruskal Wallis $H$ tests were conducted. In the study, it was discovered that the participants determined the trainers' attitude to be the most positive perception while the hygiene was the most negative perception. In the analysis of the customer satisfaction in terms of the personal information, it was determined that females' trainer perception was lower compared to men and high school graduate individuals' atmosphere perception was lower compared to the other individuals.
\end{abstract}

Keywords Sports, Fitness Centers, Customer Satisfaction

\section{Introduction}

The fact that individuals' knowledge regarding a healthy life developed, and increasing interest aimed towards a healthy life promoted the importance placed on sports. Within the scope of a perception of a healthy life, individuals inclined to utilize their free time with sports $[1,2]$. The wish to utilize free time with sports especially made individuals' interests of fitness and recreation activities more intensive. Especially the free time industry played a major part in this increase of interest. The industrial demand to include individuals' free time in the economy played a large part in the increase of interest towards sports centers $[3,4,5]$. Sports centers are characterized as private or government institutions that are oriented to provide sports service for individuals at various branches and every age. In sports centers, individuals can incline towards the sports branches they wish and can make use of their time in these places in accordance with the healthy lifestyle perception [6]. Sports facilities provide services in various branches and aim to provide individuals with a way to make use of their time. Today, the interest in popular sports, such as especially fitness and Pilates, are rather high. [4,7]. As it is in every business, sports centers are obliged to keep the customer satisfaction level high. The expansion in sports industries increased the competition in sports centers as well. In conjunction with the increased competition by the high number of sports centers in the market, sports centers that can ensure customer satisfaction can continue their existence [7]. One of the most important criteria for sports centers as service businesses to adopt has to be customer satisfaction. The high satisfaction towards sports centers can increase the demand towards the centers while low satisfaction levels decrease the demand towards the centers [8,11].The success and the profitability of sports centers are directly linked to customer satisfaction. Additionally, it is crucial for sports centers to analyze the demands and expectations of the customers and provide services in a way to meet those demands and expectations. Sports centers' adjustment of their services in line with the customers' demands and expectations and providing specialized services for customers increases the customer satisfaction [9].

Customers tend to rebuy the products or services they are satisfied with. Thus, customer satisfaction is one of the most important matters for businesses [10]. Customers are satisfied when the purchased product or service meets their demands and needs. In providing this satisfaction, the attitude of businesses towards customers gains an 
importance. Especially in service businesses, providing services in parallel with the customer demands gains significance in providing customer satisfaction [11].

The increase in the perception of individuals in making use of their free time and behavior of a health life form causes the sports industry to expand continuously. The expansion in sports industry makes the completion among sports centers more intense. Customer satisfaction plays a significant role in sports centers' continuation of their existence under these competitive conditions.

\section{Method}

\subsection{Research Model}

The research model adopted is a descriptive survey model.

\subsection{Population and Sampling}

The population of the study consists of individuals who actively go to 12 sports centers in the city of Elazı $\breve{g}$. The sample of the study consists of 113 participants who were chosen by the convenience sampling method. The involvement of the participants in the study is based on the volunteerism principle. Based on the principle of volunteerism, only a questionnaire form was conducted with the participants.

\subsection{Data-Gathering Tool}

In the study, a survey form was used as the data-gathering tool. The survey form consists of matters intended for personal information and the Sports Facilities Customer Satisfaction Scale.

The Sports Facilities Customer Satisfaction Scale was obtained from the measurement development study conducted by Yildırım (2017) [12] (Appendix-1). The scale consists of 8 sub-dimensions. The validity and reliability study of the scale was conducted by [12]. In this study, the Cronbach Alpha Coefficients were determined to be 0.712 for "Trainer Attitude" sub-dimension, 0.805 for "Support Staff Attitude" sub-dimension, 0.768 for "Personal and Social Development" sub-dimension, 0.723 for "Hygiene" sub-dimension, 0.795 for "Canteen Services" sub-dimension, 0.811 for "Program Support" sub-dimension, 0.803 for "Atmosphere" sub-dimension and 0.753 for "Suitability/Comfort" sub-dimension.

\subsection{Data Analysis}

In the study, the data analysis was conducted by using the SPSS 21 package software. In the data analysis, descriptive statistics such as frequency, percentage, mean, standard deviation, minimum and maximum calculations were used. Additionally, in order to determine the relationship between the personal information and the sports facilities customer satisfaction, Mann Whitney U and Kruskal Wallis $\mathrm{H}$ tests were conducted. While choosing these tests, Kolmogorov Smirnov test was made use of. It was determined that none of the sub-dimensions provides a normality assumption and non-parametric tests, Mann Whitney $\mathrm{U}$ and Kruskal Wallis $\mathrm{H}$ tests, were conducted. Mann-Whitney $U$ test is used for determining the differences between two samples and its significance is determined according to the "Z Normal Distribution" statistics. Kruskal Wallis $\mathrm{H}$ test is used for determining the difference between three or more samples, and the " $\mathrm{X}^{2}$ " distribution is utilized.

\section{Findings}

Table 1. Findings Regarding Personal Information

\begin{tabular}{|c|c|c|}
\hline & Frequency & $\%$ \\
\hline \multicolumn{3}{|l|}{ Gender } \\
\hline Male & 55 & 48.7 \\
\hline Female & 58 & 51.3 \\
\hline \multicolumn{3}{|l|}{ Age } \\
\hline $\begin{array}{l}20 \text { years old and } \\
\text { below }\end{array}$ & 33 & 29.2 \\
\hline 21-30 years old & 58 & 51.3 \\
\hline $31-40$ years old & 15 & 13.3 \\
\hline 41 years old and above & 7 & 6.2 \\
\hline \multicolumn{3}{|l|}{ Marital Status } \\
\hline Married & 23 & 20.4 \\
\hline Single & 82 & 72.6 \\
\hline Divorced & 4 & 3.5 \\
\hline Widowed & 4 & 3.5 \\
\hline \multicolumn{3}{|l|}{ Education Level } \\
\hline Primary School & 5 & 4.4 \\
\hline Secondary School & 7 & 6.2 \\
\hline High School & 15 & 13.3 \\
\hline University & 79 & 69.9 \\
\hline Postgraduate & 7 & 6.2 \\
\hline \multicolumn{3}{|l|}{ Regular Exercise } \\
\hline 3 months and below & 63 & 55.8 \\
\hline 4-11 months & 24 & 21.2 \\
\hline $1-2$ years & 17 & 15.0 \\
\hline $3-5$ years & 5 & 4.4 \\
\hline 5 years above & 4 & 3.5 \\
\hline
\end{tabular}

It was determined that $51.3 \%$ of the participants were females, $51.3 \%$ were between $21-30$ years old, $72.6 \%$ were single, $69.9 \%$ were university graduates and $55.8 \%$ were exercising regularly for 3 months and below. 
Table 2. Findings Regarding the Sports Centers Customer Satisfaction Scale

\begin{tabular}{cccccccc} 
& $\mathrm{N}$ & Minimum & Maximum & Mean & Std. Deviation & K-S Z & $\mathrm{p}$ \\
\hline Trainer Attitude & 108 & 7.00 & 27.00 & 3.46 & 4.89 & 2.303 & 0.000 \\
Support Staff Attitude & 107 & 4.00 & 15.00 & 3.42 & 3.04 & 2.373 & 0.000 \\
Personal and Social Development & 108 & 4.00 & 28.00 & 3.30 & 3.43 & 2.154 & 0.000 \\
Hygiene & 108 & 4.00 & 19.00 & 3.14 & 3.47 & 1.992 & 0.001 \\
Canteen Services & 105 & 4.00 & 19.00 & 3.19 & 3.25 & 1.651 & 0.009 \\
Program Support & 105 & 3.00 & 14.00 & 3.41 & 2.27 & 2.449 & 0.000 \\
Atmosphere & 108 & 4.00 & 20.00 & 3.21 & 3.52 & 2.088 & 0.000 \\
Suitability/Comfort & 112 & 2.00 & 10.00 & 3.15 & 2.03 & 2.661 & 0.000 \\
\hline
\end{tabular}

Table 3. Sports Centers Customer Satisfaction according to Personal Information

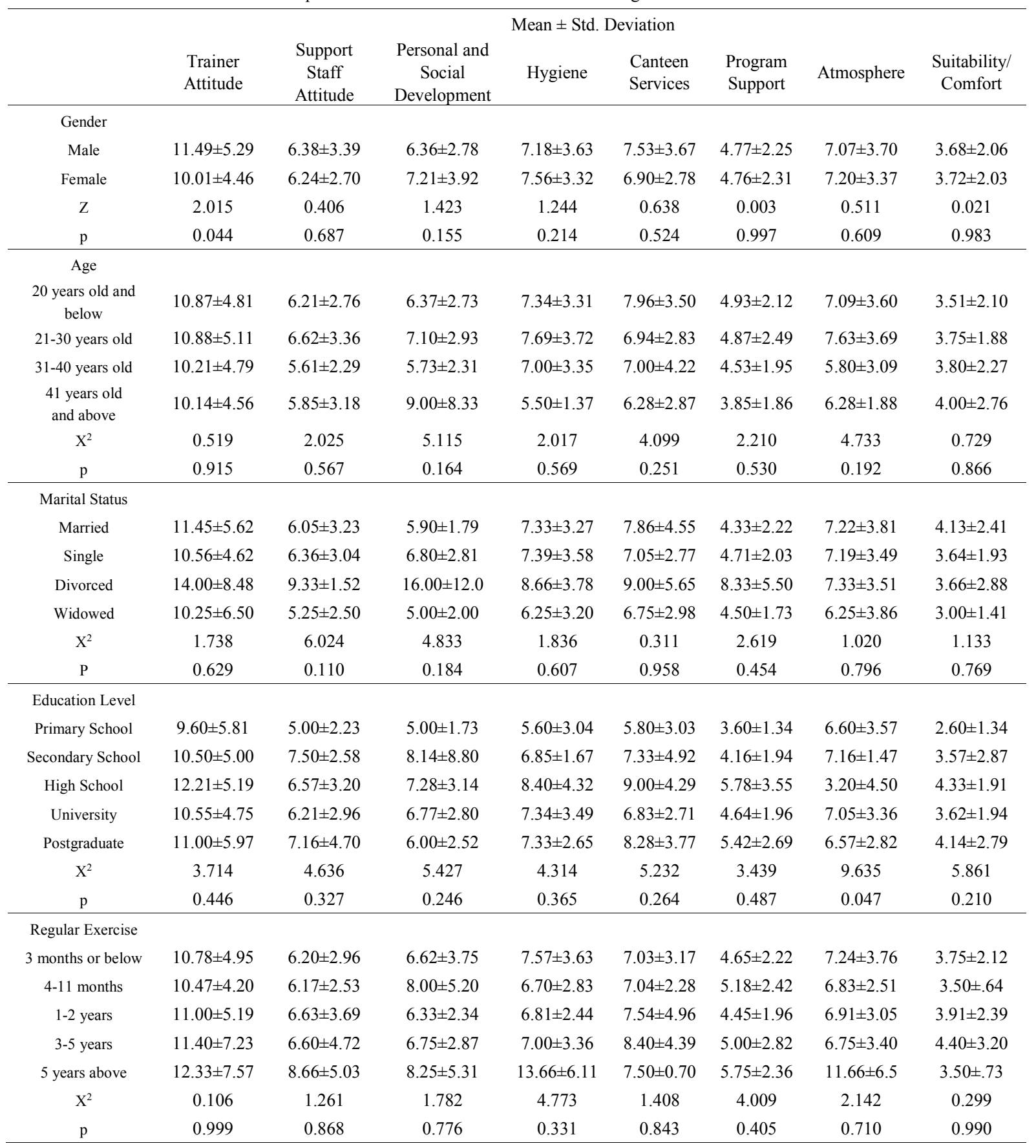


In the analysis of the Sports Centers Customer Satisfaction Scale, it was observed that the mean values were above 3 . This indicates that participants are generally satisfied with the sports facility. Additionally, the highest mean value is of trainer approach with 3.46 while the lowest mean value is of hygiene with 3.14 . The most positive perception of the participants towards the sports facility is the trainer approach while the most negative one is hygiene.

In the analysis of the findings regarding the Sports Centers Customer Satisfaction Scale, it was determined that no sub-dimension provided the normality assumption $(\mathrm{p}<0.05)$ and it was decided to make use of non-parametric tests, Mann Whitney U and Kruskal Wallis $\mathrm{H}$ tests.

In the analysis of the customer satisfaction according to the personal information, it was determined that there were statistically significant differences in the perception of trainers according to gender and in the perception of atmosphere according to education level $(\mathrm{p}<0.05)$. The trainer perceptions of females $(10.01 \pm 4.46)$ were lower than the trainer perceptions of males $(11.49 \pm 5.29)$. The atmosphere perceptions of individuals who are high school graduates $(3.20 \pm 4.50)$ are lower compared to the other individuals.

\section{Conclusions}

The differentiation in individuals' perception of making use of their free time and the sports industries' fill of this significant gap in free time consideration increased the demand for sports centers. Today, a number of sports centers are in service and competition conditions are rather intense. In the sports centers' continuation of their existence in these competitive conditions, customer satisfaction is assessed as a significant factor.

In this study, sports centers' customer satisfaction was investigated. In the study, it was determined that the most positive perception of participants was trainer attitude while the most negative one was hygiene. The state of hygiene in sports facilities affects participants' satisfaction levels negatively. In the analysis of the customer satisfaction according to personal information, it was determined that the trainer attitude perceptions of females were lower compared to those of males and the atmosphere perceptions of individuals who are high school graduates were lower compared to other individuals.

The suggestions within the framework of the study are as the following:

- Providing the required hygienic conditions in sports centers will affect customer satisfaction positively.

- General and personal hygiene conditions should be paid attention.

- Atmosphere is of importance in sports centers. Designing sports centers according to the target population will be vital in terms of the customer satisfaction.

- Coaches' attitudes were evaluated to be important for customers. Thus, having specialist and educated coaches in their fields is an important factor in terms of customer satisfaction.

- This study was conducted only with customers. In further studies, coaches' satisfaction states could be investigated and compared.

- This study was conducted by using only the quantitative data analysis technique. Further studies could conduct interviews, making use of the qualitative data analysis techniques, and deeper analyses could be conducted.

\section{REFERENCES}

[1] Breuer, C., Feiler, S., \& Wicker, P. (2015). Sport clubs in Germany. In Sport clubs in Europe (pp. 187-208). Springer, Cham.

[2] Durhan, T. A., Akgül, B. M., \& Karaküçük, S. (2017). An Evaluation of Spare Time Management of Individuals Who Are Interested In Swimming for Recreation Purposes. Journal of Physical Education and Sports Sciences, 19(4), 8-16.

[3] Atasoy, B., \& Kuter, F. Ö. (2015). Globalization and Sports. Uludağ University Journal of Education Faculty, 18(1), $11-22$.

[4] Mclean, D. and Hurd, A. (2012). Recreation and Leisure in Modern Society. London: Jones \& Bartlett Learning.

[5] Koçak, Y., Tukul, U., Tolan, B., Gümüş, H., \& Tolukan, E. (2017). Analysis of Customer Expectations and Perceptions of Service Quality in Sports and Healthy Life Centers (A sample of the city of Afyonkarahisar). International Journal of Recreation and Sports Science, 1(1), 38-46.

[6] Bosnjak, M., Brown, C. A., Lee, D. J., Yu, G. B., \& Sirgy, M. J. (2016). Self-expressiveness in sport tourism: Determinants and consequences. Journal of Travel Research, 55(1), 125-134.

[7] Yu, H. S., Zhang, J. J., Kim, D. H., Chen, K. K., Henderson, C., Min, S. D., \& Huang, H. (2014). Service quality, perceived value, customer satisfaction, and behavioral intention among fitness center members aged 60 years and over. Social Behavior and Personality: an international journal, 42(5), 757-767.

[8] Calabuig, F., Núñez-Pomar, J., Prado-Gascó, V., \& Añó, V. (2014). Effect of price increases on future intentions of sport consumers. Journal of business research, 67(5), 729-733.

[9] Andreasson, J., \& Johansson, T. (2014). The fitness revolution. Historical transformations in the global gym and fitness culture. Sport science review, 23(3-4), 91-111.

[10] Korkmaz, H., Giritlioglu, İ., \& Avcikurt, C. (2015). The Effect of Perceived Service Quality in Domestic Airlines on 
Customer Satisfaction and the behavior or Rebuying. Karabük University Journal of Institute of Social Sciences, 5(2), 248-265.

[11] Khuluq, A., Hasiholan, L. B., \& Warso, M. M. (2016). Effect of Price, Facilities and Quality of Service Loyalty and Satisfaction of Visitors Visitors as Intervening Variable
Gardenia in Sport Center in Semarang. Journal of Management, 2(2).

[12] Yildırım, M. (2017). Sports Facilities Customer Satisfaction Measures Development: Validity and Reliability Study. 21. Journal of Education and Society in the $21^{\text {st }}$ Century, 6(16), 157-176. 